\title{
Methods of Government Negligence Protection for Provision of Physical Activities
}

\section{Merry Moiseichik}

\begin{abstract}
The purpose of this article is to identify how the balance between the competing interests of citizens' need to recover damages from injury and the governments' interest for providing services without jeopardizing community budgets is accomplished. The article examines the different mechanisms used for negligence protection and how they have changed over time to create that balance. Using content analysis, all 50 state laws concerning tort immunity, recreation land use statutes, hazardous recreation statutes and insurance award caps in tort claims acts were reviewed. The hypothesis that if a state waived immunity, the state would find another method to protect communities so that they could provide the activities their citizens demanded was shown to be true. All but seven states have found a method to protect themselves and provide services.
\end{abstract}

"Fearing Lawsuit Omaha Closes 2 Sledding Hills" was a headline from the Omaha World-Herald on January 4, 2007. That headline identified the reaction to a Dawes County law suit (Bronsen v. Dawes County, 2006) which ruled Recreation Land Use Statute in Nebraska would not protect publicly-owned land. This decision caused recreation directors to close skate parks, ice rinks, bike trails and sled hills in cities that could not purchase liability insurance and no longer had statutory protection for negligence (Sloan, 2007). There was a public outcry to have their recreation facilities reopened. On May 16, 2007, only five months later, the state passed legislation giving back liability protection to municipalities. A section was added to Nebraska's tort claims act that would be an exception for lawsuits if an injury occurred on publicly-owned land that was provided for the purpose of recreation (R.R.S. Neb. § 13-910 (2011)).

The Nebraska example is a perfect illustration of the tension of city parks and public recreation officials having protection from lawsuit, losing that protection, and then getting it back through new legislation. Public recreation directors want to provide services to their citizens, but they also want to protect their city coffers from a lawsuit that may cost millions. On the other hand citizens who have been injured through ordinary negligence on the part of a city agent want the right to collect on their injury.

Moiseichik (merry@uark.edu) is with the Dept. of Health, Human Performance, and Recreation, University of Arkansas, Fayetteville, AR. 
The purpose of this article is to identify how the balance between the competing interests: the citizens' needs to recover damages from injury vs. the government's interest for providing services without jeopardizing community budgets. If the public agency provides hazardous recreation pursuits and is not protected from negligence suits, it stands to lose millions of dollars in individual law suits. If the city chooses not to provide facilities and programs citizens demand, the recreation department gets severely criticized. This article examines the different mechanisms used for negligence protection and how they have changed over time to create a workable balance.

\section{Sovereign Immunity History}

Sovereign immunity has a long history in the United States. It is the principle that government should not be sued without permission from Congress. Chisolm v. Georgia (1793) was the first legal action brought to the United States Supreme Court to decide if citizens could sue a state to recover damages. Justice Iredell in a dissenting opinion stated that without other laws passed in the United States, the common law of England must be followed. In England one could not bring a case before the king without his permission. Iredell believed that a case could not be brought against the United States federal government or any state government without their permission (Chisolm v. Georgia, 1793). Since public and political opinion sided with Iredell, the 11th Amendment was ratified five years later to overturn the state suability determination in Chisolm (Pfander, 1998):

The judicial power of the United States shall not be construed to extend to any suit in law or equity, commenced or prosecuted against one of the United States by Citizens of another State, or by Citizens or Subjects of any Foreign State. (U.S. Const. amend. XI)

If a citizen was injured by the government, he or she could only sue through a private bill passed in Congress allowing the suit. That is, if a citizen was injured by the government's mistake, he had to request the state or federal legislators to allow him to bring a suit to court against the government. This "private bill" gave permission to the citizen to go to court. Several presidents had urged Congress to change the law requiring private bills to sue a government entity. According to John Quincy Adams, half of Congress' time was being spent on private bills. In the 1880s Congress had between 1000 and 2000 private bills per session (Nelson, 2009).

Private citizens also complained that the private bill requirement to sue a government was unjust and "wrought with political favoritism" (Nelson, 2009, 267). Lobbyists were needed to get the private bills passed by Congress and one commentator stated "these "agents" or "brokers" would slip their private bills through Congress in a manner that "would shock the sense of justice if the facts against them were made known by an open trial." (Nelson, 2009, p. 304)

In 1921, Congress attempted to pass a tort claims act to correct some of these problems yet it was not until July 28, 1945 when an Army bomber plane accidently flew into the Empire State Building killing and injuring people in the building and on the streets that serious discussions actually occurred. This accident created an untenable public relations position for the federal government when the injured 
citizens had no easy recourse for their damages (Zabel, 2003). Largely because of this incident Congress approved The Federal Tort Claims Act (FTCA) in 1946. "The FTCA was thus a response to the perceived unfairness of failing to allow tort suits against the federal government, as well as a solution to the burden of responding to private bills for relief requiring individual congressional consideration" (Zabel, 2003, p. 194). The act states,

The United States shall be liable, respecting the provisions of this title relating to tort claims, in the same manner and to the same extent as a private individual under like circumstances, but shall not be liable for interest prior to judgment or for punitive damages. (28 USCS $§ 2674$ )

Thus the federal government of the United States gave up its immunity rights with some states following suit. Since recreation activities have inherent risk and injuries cost money, the victims of accidents often want to find someone to blame as a way to pay for the high cost of injury, thus targeting the provider of the service. Immunity laws protect the government but at the same time may not give a method of recovery to a participant who gets hurt through a negligent act of the provider. With each state considering the issue, the hypothesis for this study is that as immunity is waived for negligence for provision of recreation services, states will eventually pass another statute so that recreation providers can continue to offer services that are demanded by the public.

\section{Methodology}

A qualitative content analysis of each state's tort claims act, recreation user statutes, and special hazardous recreation statutes was completed. Content analysis is a replicable, systematic examination of the statutes looking for themes, patterns, trends and longitudinal changes to draw inferences. This method was favored over legal analysis because of it rigor, ability for replication, breadth, and distinctive insights (Hall \& Wright, 2006).

Systematic recording and coding of consistent features across state statutes were implemented. If a statute was written for a single activity like equine or skiing, it was not included in this study. Since tort claims acts go well beyond recreation and sport, while reviewing statutes special attention was paid to parks, recreation and sport discussions. For example, if a state has a general immunity exception for recreational activities, it was considered not to have immunity, even though it may have immunity for other governmental services. This study is delimited to the status of immunity for parks, recreation and sport and to no other governmental services. Lexis Nexis Academic 2013 was used for all laws. To be thorough, search words included tort claims, immunity, recreation, hazardous recreation, recreation land use, recreation user, and sport. Although case law is often the impetus for legislation, this study only considered the actual statutes.

The content analysis included how immunity was treated, exceptions to the stated law, what recreational activities were included or excluded, whether it included public or private, historical revisions, and dates passed and revised. It is not the intent of this article to discuss every state law as it relates to this topic, however, Table 1 provides a list of all the state laws that were reviewed, Figure 1 
is a map developed to indicate the strongest statute in each state that provides negligence protection for city parks and recreation and sport agencies. For example, if the state had blanket immunity with limited exceptions, that would be the strongest level of protection. If immunity was waived, the recreation user statutes and hazardous recreation laws were considered. If two statutes provided protection, the one that seemed to provide the strongest protection was used. For example Alabama has sovereign immunity but it does not extend to municipalities (Code of Ala $\S$ 11-47-190 (1996)). That was passed in 1965. In 1981 Alabama Recreation User Statute extended to public improved land for noncommercial outdoor recreation Ala.Code Art. 2\$ 35-15-20 (1981). In 1996 Alabama capped the amount of liability to $\$ 300,000$. Alabama has no hazardous recreation statute. It was determined that the liability cap gave the strongest protection to municipalities, therefore, insurance cap was selected as having the greatest protection for recreation and sport activities (see Figure 1).

Finally, dates of statute changes were used to create a graphic depiction for when laws changed. Note was made as to when a state waived immunity and when other statutes were enacted thus providing an indication of legislative reform over time. The dates included in Table 1 are the original passage date. While many of the laws may have been updated, renumbered, or revised, the original passage is the one identified. All 2013 statutes were reread multiple times to check for accuracy.

\section{Types of Negligence Protection}

Four types of protections were examined: Sovereign Immunity or Tort Claims Acts, Recreation Land Use or Recreation User Statutes, and Hazardous Recreation or Special Recreation Statutes. Within the Tort Claims Acts, caps on the claims were added over time and these were added as a fourth category for protection.

\section{Sovereign Immunity}

Sovereign immunity means that a government cannot be sued for ordinary negligent action. Each state determines its own immunity status. Some states have maintained their immunity provided by the 11th Amendment mentioned earlier, while other states felt the need to drop it, following the lead of the federal government in 1946.

An example of an existing strong immunity law is the Arkansas statute, which rests in its constitution and states "The government shall not be a defendant in her courts" (ACA 21-9-301+). This was codified in 1874 and means that if an action of any governmental agent causes injury through ordinary negligence; the injured party cannot take the agent or the governmental entity to court and therefore cannot bring a suit. Arkansas law appears to be one of the strongest immunity laws in the country as it is part of the Arkansas Constitution making it difficult to change. In its simplicity, it is clear in its intent. Since its inception, exceptions have passed but only for three reasons. Arkansas can be sued for transportation issues (A.C.A. § 21-9-303 (2011)), up to the amount of an insurance policy (A.C.A. § 21-9-301 (2011)), and for claims brought through the claims commission, similar to what the federal government had where the legislature can pass legislation to allow a "private suit against the government in the event that they agree that the citizen had been significantly wronged" (A.C.A. § 19-10-201 (2011). These exceptions 


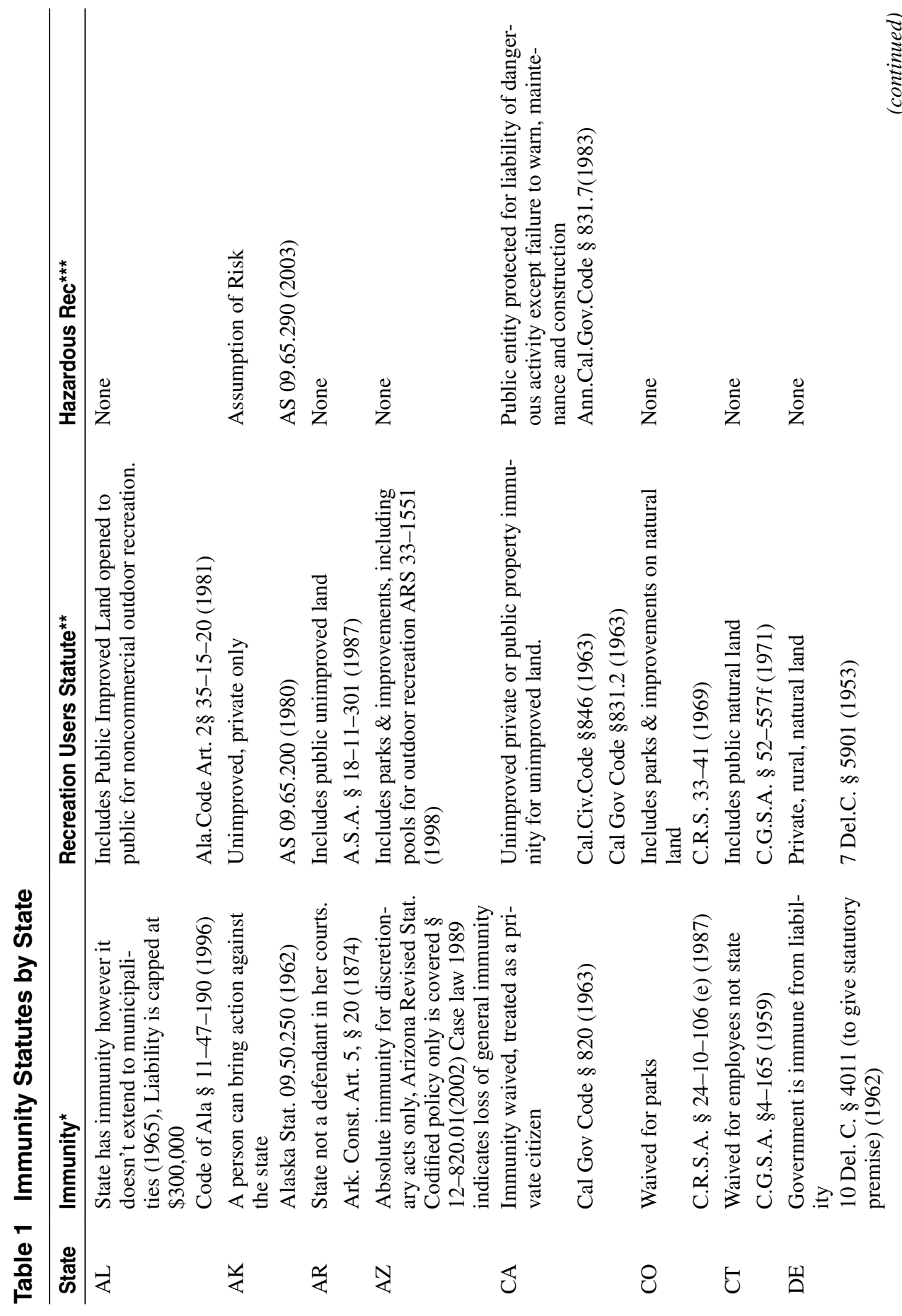




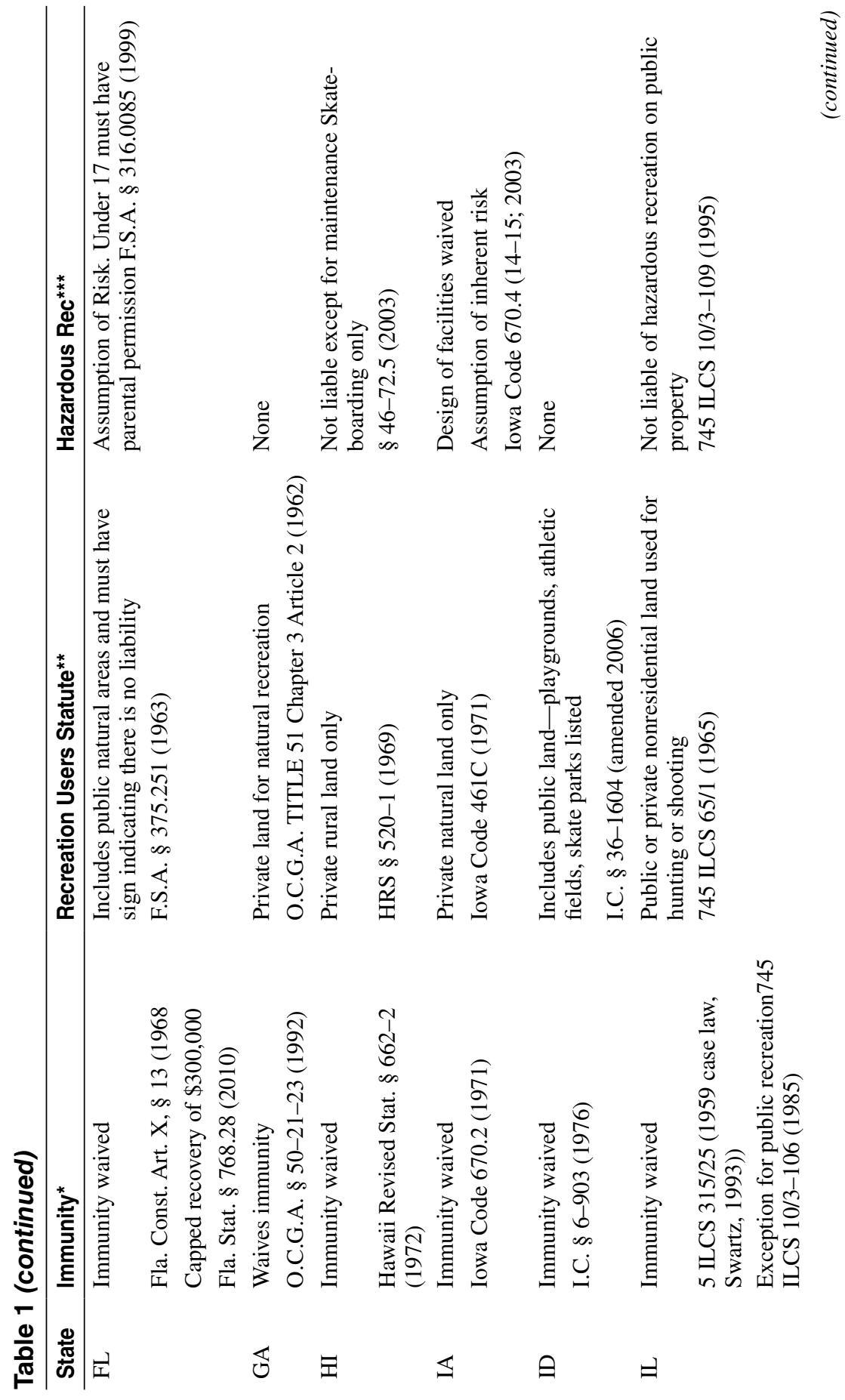




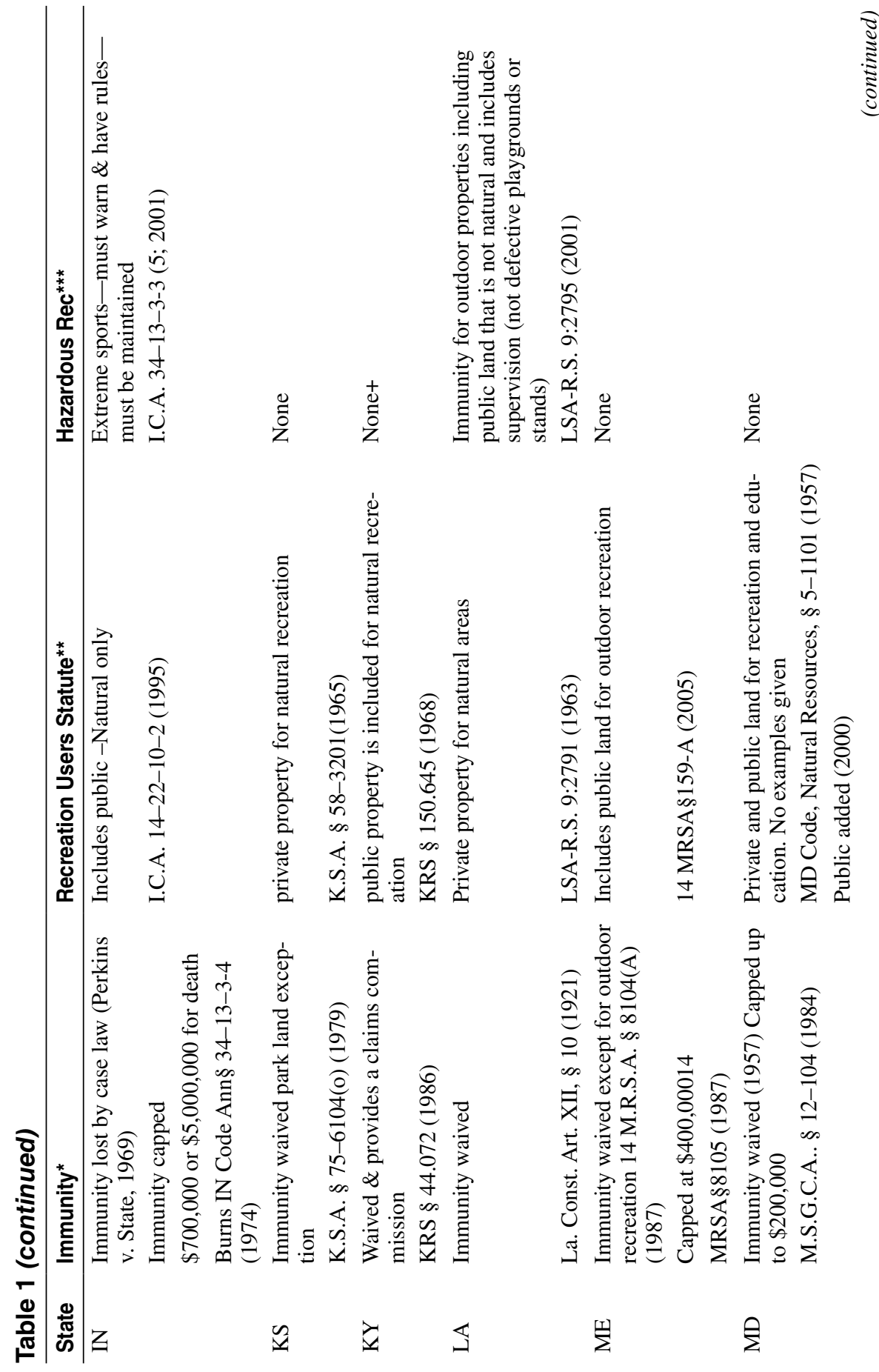




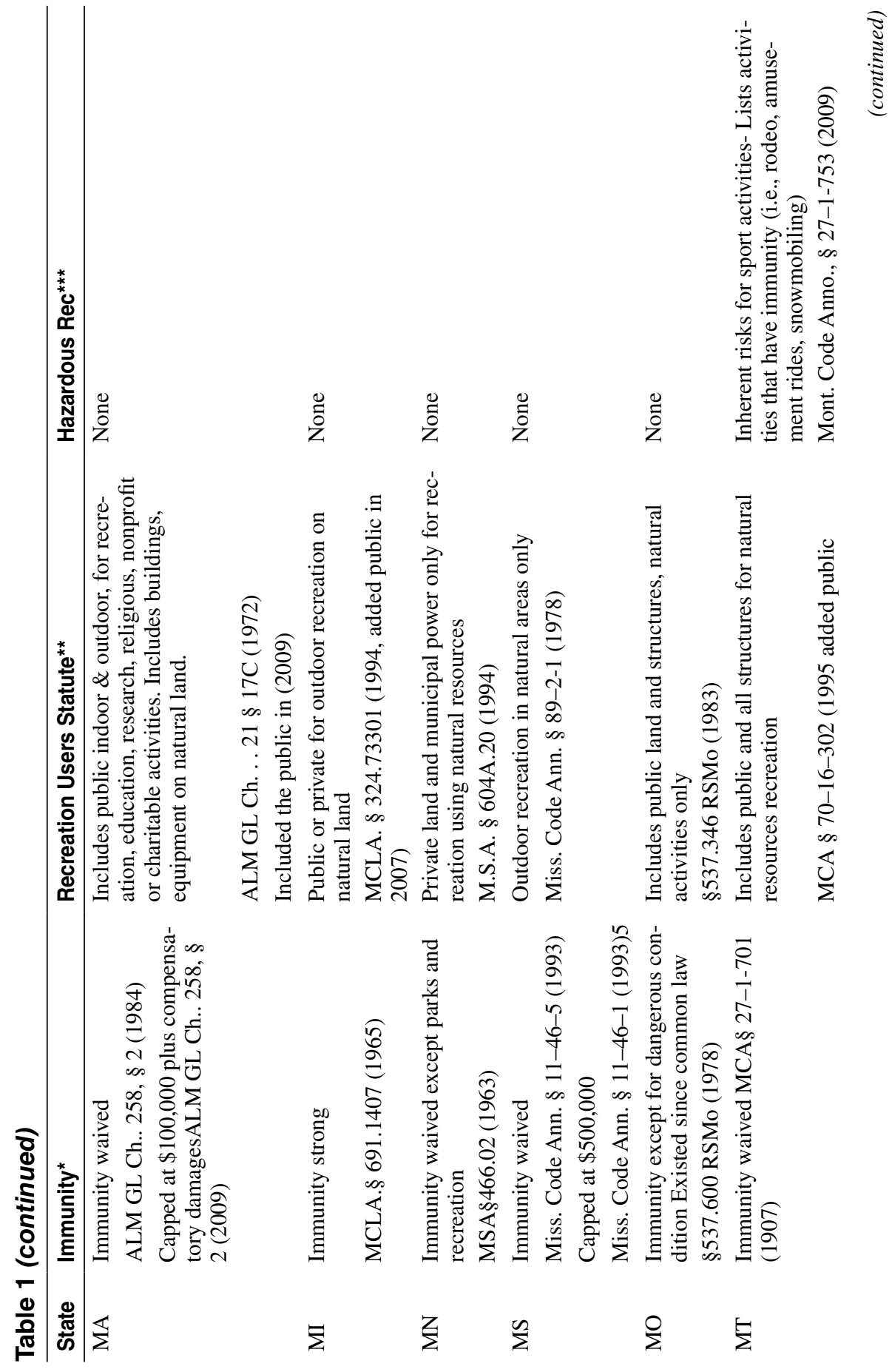




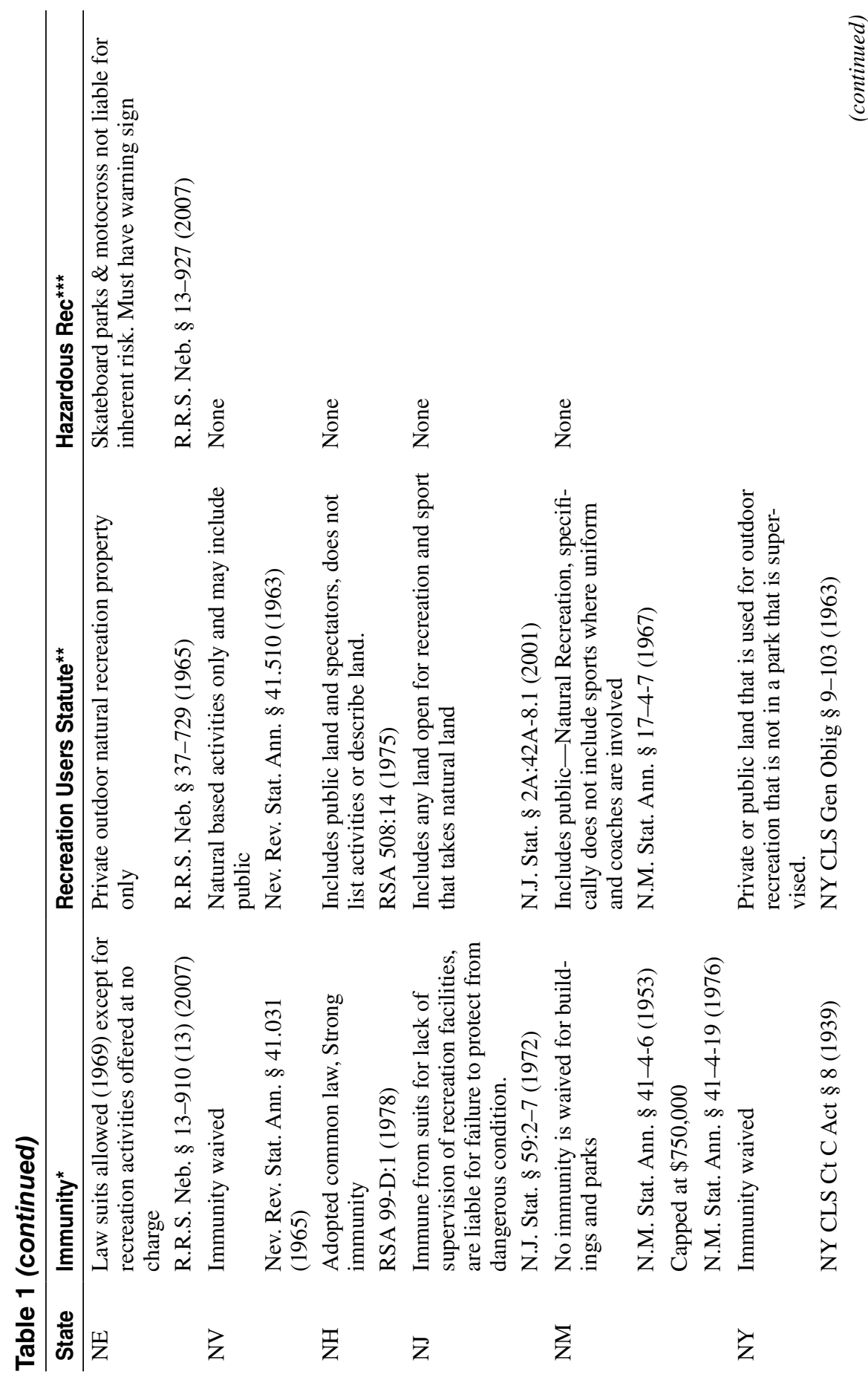




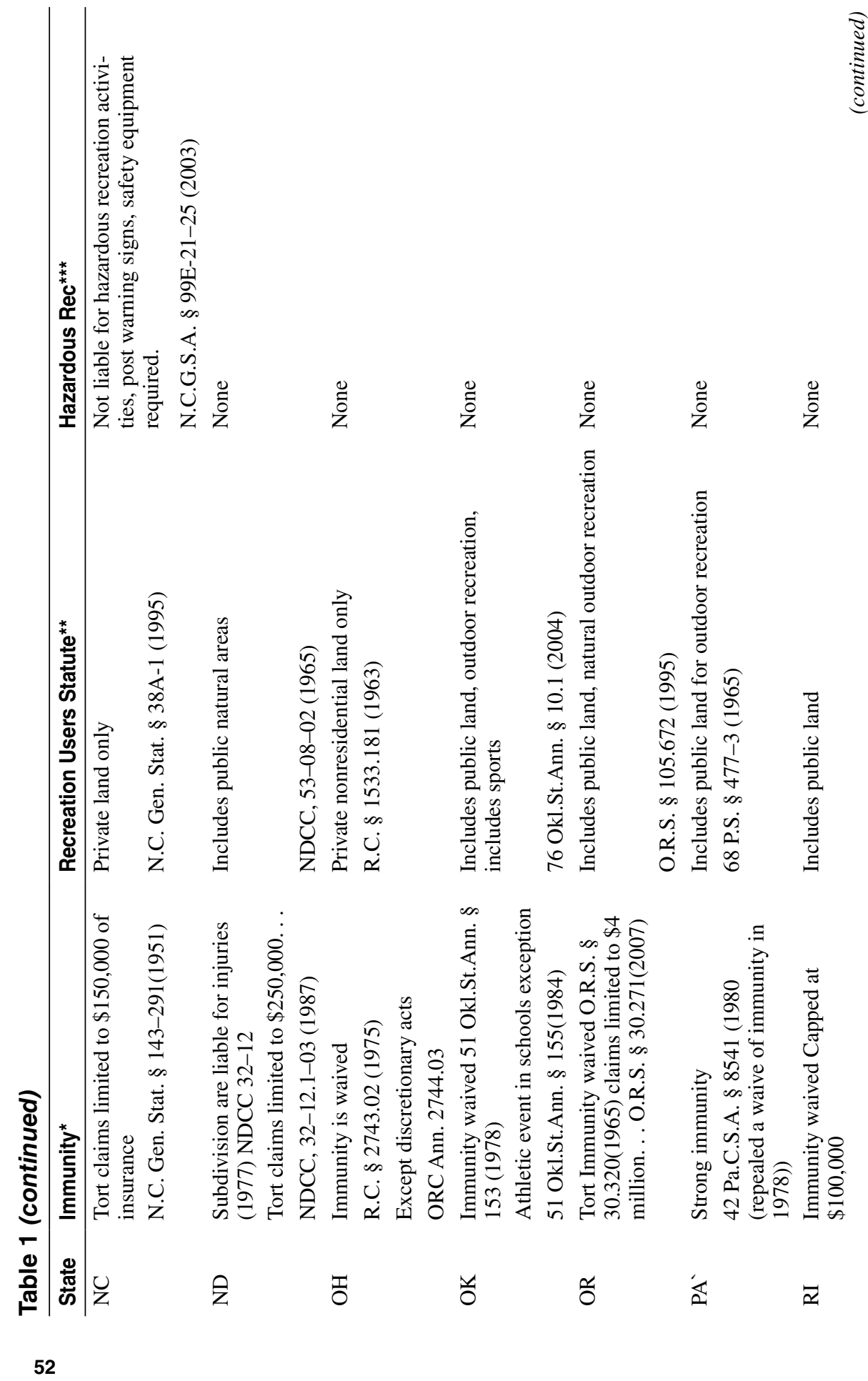




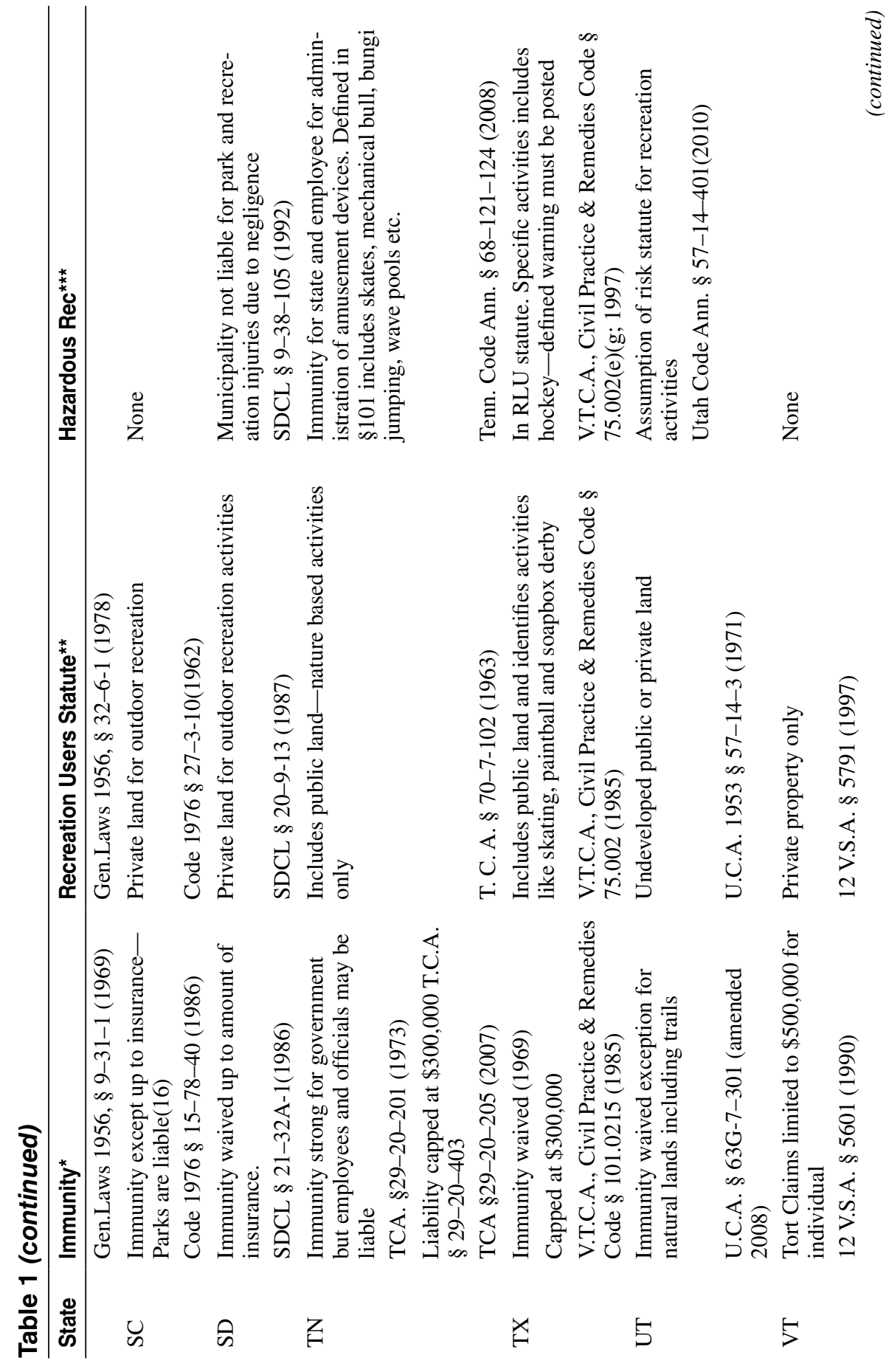




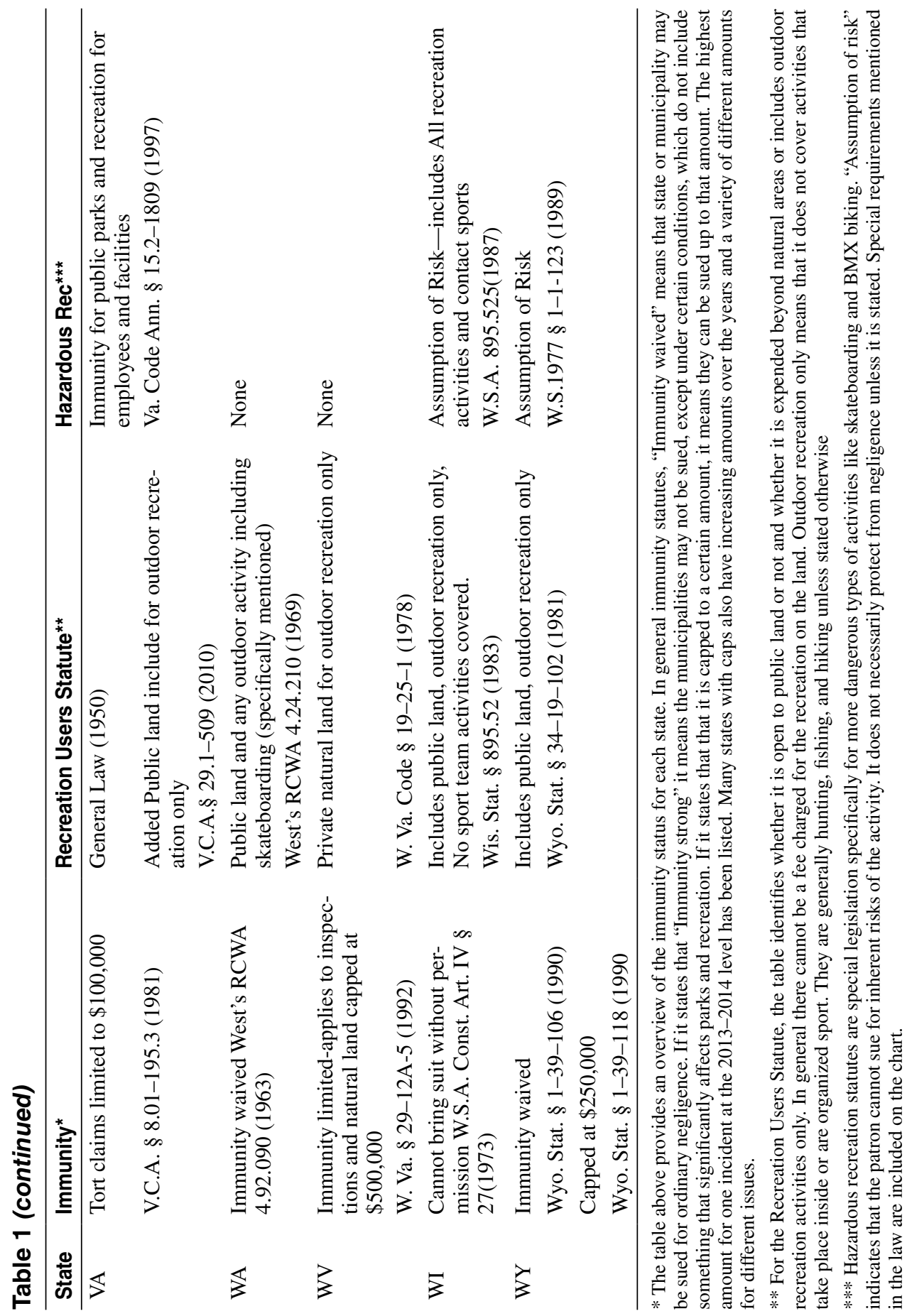




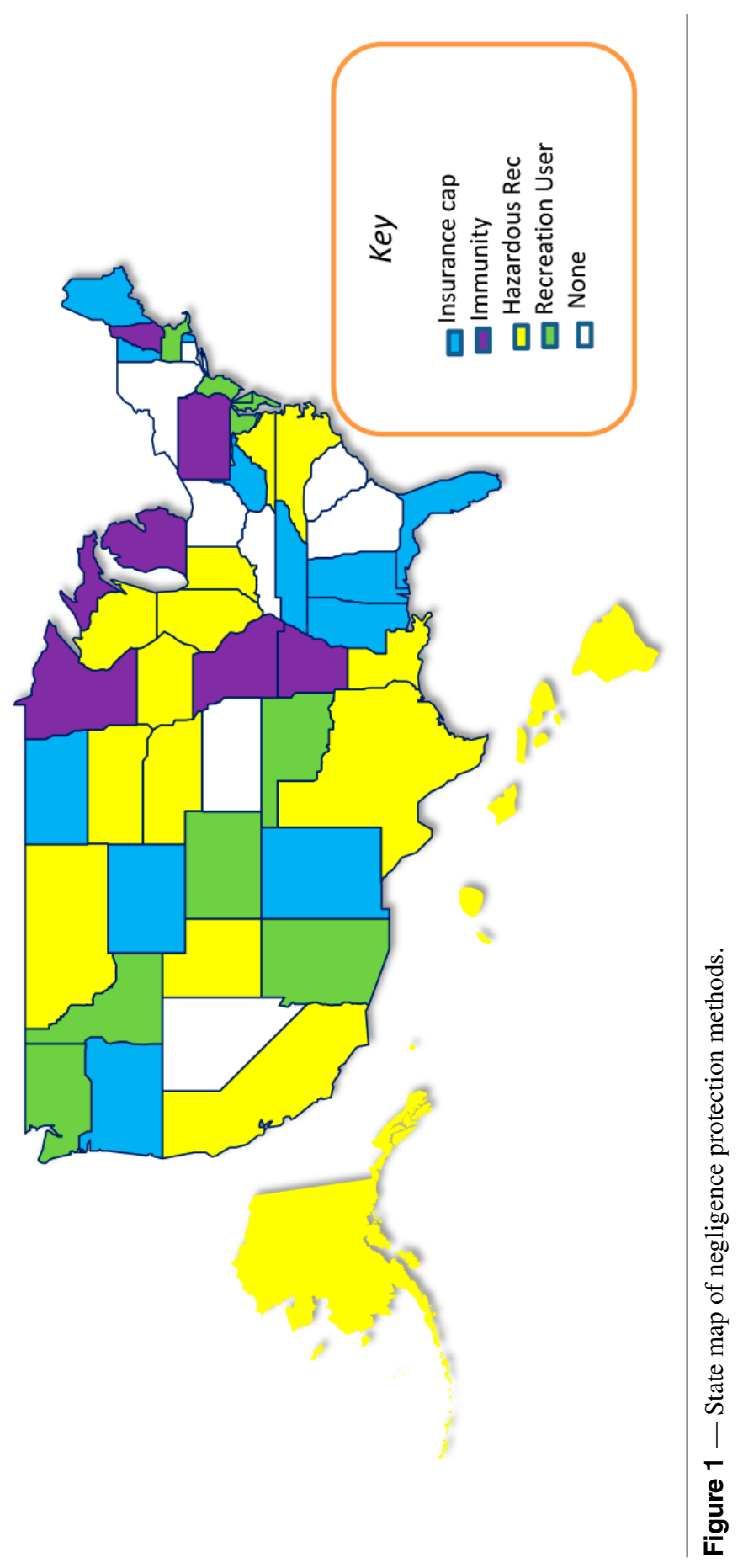


are typical to other states with strong immunity. Mississippi, Michigan, and New Hampshire, also seem to have fairly strong immunity laws.

On the other hand, some states appear to have governmental immunity, but it is restricted by some other statute that diminishes its strength. For example, Colorado law states "A public entity shall be immune from liability in all claims for injury which lie in tort or could lie in tort..." (C.R.S.A. § 24-10-106, 2013) but then it goes on to list exceptions. Since a Colorado exception is "A dangerous condition of any public hospital, jail, public facility located in any park or recreation area maintained by a public entity, or public water, gas, sanitation, electrical, power, or swimming facility." (emphasis added; Section 1(e)). Colorado law is not considered a strong immunity statute. Because of this exception, there is no governmental immunity for the provision of recreation and parks in Colorado.

Every state has exceptions for their immunity including Arkansas. All states exclude gross or willful and wanton negligence, ultra vires acts or those acts outside of employees' scope of duty, as well as if a public entity has liability insurance. Some other exceptions include special activities like transportation or special facilities like pools or playgrounds. All states with immunity allow the government to be petitioned for a suit if the plaintiff feels she has been unfairly wronged. Since each state has many exceptions, knowing one's own state law is important.

Most states, like the federal government, had sovereign immunity. Many states changed their laws after WWII, again following the federal government and gave up their immunity. These states had the same issues as the federal government, which included legislature time being taken up for permission to sue (similar to personal bills in the federal government), the unfairness of the government having immunity from paying for injuries they caused, unclear exceptions, and state judges making decisions that sided with citizens in negligence cases. These matters were the impetus for states to waive their immunity.

When states give up their immunity, they can then be sued for injury due to negligence. Examples of Louisiana and Hawaii legislation are some of the simplest of these statutes. Louisiana's legislation reads "Neither the state, a state agency, nor a political subdivision shall be immune from suit and liability in contract or for injury to person or property" (La. Const. Art. XII, § 10 (2013)). Or from Hawaii:

The State hereby waives its immunity for liability for the torts of its employees and shall be liable in the same manner and to the same extent as a private individual under like circumstances, but shall not be liable for interest prior to judgment or for punitive damages. (HRS § 662-2(2013))

When states passed these pieces of legislation, local governments and therefore public park and recreation departments were opened to liability for negligence. As a result some communities were reluctant to offer activities considered to have higher risk, like skateboard parks, because they were unprotected. As the laws changed, many states turned to recreation land use statutes for protection from suit.

\section{Recreation Land Use Statutes}

The purpose of Recreation Land Use statutes or recreation users statutes was to encourage private land owners to open their land to the public for recreational activities because outdoor recreation pursuits, like hunting, fishing, 4-wheeling, 
etc., take lots of space (Carroll, Connaughton, \& Spengler, 2007). Many privately owned acres could be used for outdoor recreational pursuits but private land owners were hesitant to let the public use their land for fear of litigation if someone were hurt. At the same time the demand for outdoor pursuits was growing (Carroll, Connaughton, and Spenger, 2007). In 1950, Virginia was the first state to pass a recreation user statute, Va. Code Ann. $§ 29.1-509$ (2011). In 1965, the Council of State Governments passed a model act, a form of which has been adopted by all 50 states (Dickey v. City of Flagstaff, 2003).

The land owners were protected so that they did not have to make any changes to their property if public was to use it. The Delaware statute, typical of most states, reads,

... an owner of land owes no duty of care to keep the premises safe for entry or use by others for recreational purposes, or to give any warning of a dangerous condition, use, structure or activity on such premises to persons entering for such purposes. The limitation of duty of the owner granted by this section applies whether such persons entered upon the land of the owner with or without consent of the owner. (7 Del.C. $§ 5903,(2013)$ )

While the protection is for landowners, some states specify it is only for privately owned land (e.g., DE, Fl, MN, NE, VT, and VA; see Table 1) others were more ambiguous. As one can see from the Nebraska example at the beginning of this article, many states tried to expand the recreational user statutes to protect the public land holders that did not charge a fee for activities on their land. Nebraska's statute read "... to encourage owners of land to make available to the public land and water areas for recreational purposes" (R.R.S. Neb. § 37-730 (2013)). Since the statute did not specifically state "private land," it was broadened to public land until Bronsen v. Dawes Co. (2006) Branson stepped in a hole on the Dawes County courthouse lawn while attending a free concert. The appeals court ruled that under the Nebraska Recreational User statute a citizen could not sue for ordinary negligence (Bronsen v. Dawes Co. (2005)). However, the Nebraska Supreme Court overruled this decision because they said one should not have to look at what a person was doing at the court house to determine if they could sue (Bronsen $v$. Dawes Co. (2006)). If the person had been walking across the lawn to use the court house for business, they would have been allowed to sue. Therefore, the Nebraska Recreational User statute was struck down for public land.

Another stipulation of the recreational user statutes was to protect undeveloped land (Kaiser \& Wright, 1994). This meant that if the statute was extended to public property, it would not protect any activities that included developed facilities. While it might protect hunting and fishing that occurs on natural terrain, it certainly would not include constructed facilities such as ball fields, skate parks, or swimming pools. But, as governmental immunity was waived by state legislatures, many recreation user statutes were added or broadened to include developed areas as well. In the legislative intent of the Arizona recreation user statute it is stated,

Arizona Supreme Court abolished the common law rule of sovereign immunity, in doing so, however, it acknowledged that municipalities acting in a governmental capacity had historically been immune from negligence actions; moreover, the court invited the legislature to enact laws to protect the public 
and those it deemed "necessary to avoid a severe hampering of a governmental function or thwarting of established public policy." (A.R.S. § 33-1551 (2013))

Arizona then included parks and outdoor school grounds with facilities like playgrounds and ball courts, they still excluded swimming pools.

Idaho waived governmental immunity in 1976 (Idaho Code § 6-903 (2011)) and in 1979 the Limited Liability of Landowners statute was passed and included recreational activities on public land that did not charge a fee (I.C. § 36-1604). They included playgrounds, athletic events, and skateboarding as being protected from liability, thus broadening the recreational user statute. Similarly, other states including more than natural areas are California, Connecticut, Kentucky, Maine, and Wisconsin (see Table 1).

So for many states, as they lost their sovereign immunity, administrators began looking for ways to get some kind of protection to provide activities and facilities that are sometimes perceived as risky, like skateboard parks or sledding on park hills. Since injuries occur during recreation activities the fear of lawsuits encouraged evaluation of laws that could be used for protection. Recreational user statutes were an obvious option. But, as in Nebraska, not all states made changes to recreational user statutes or agreed that they could be used for public recreation and parks.

\section{Hazardous Recreation Statutes}

Since public interest started to grow for more activities with greater risks in the 1970s and 80's those states that did not have protection for negligence refused to offer certain activities. Skateboarding is an example of one of those activities becoming more popular with kids skating on the sidewalks and steps of public buildings. Many city administrators complained that the skateboarders were "dangerous to lives and destructive to property" (Schogol, 2002, p. 1) and for that reason cities began banning the activity on public property. The citizens demanded a place to pursue their interest, but the administrators were afraid of law suits. In St Petersburg, FL the police began fining skateboarders claiming they were creating a potentially dangerous situation (Latoof \& Gofen, 1988). The skateboarders wen-t to city hall for help. "The Florida League of Cities told the city "the liability potential [on a skateboard park] could be astronomical. The bodies of these children are still developing. The appearance of paralyzed children in the courtroom tends to bring out the generosity in jurors" (Sutton, 1988, p.1). While the city wanted to provide the park, they had no liability protection and insurance on the facilities was too expensive.

In 1973, Florida waived its immunity (F.S.A. § 768.28,(2013)). Its recreational user statute was classic in that it covered typical outdoor recreation activities like hunting and fishing. Florida's statute read that protection covered hunting, fishing and boating (F.S.A. § 375.251 (2013)) and mentioned nothing about an activity that took special facilities like a skate park. In 1999 the Florida legislature passed a hazardous recreation statute (West's F.S.A. $\$ 316.0085$ (2013), which stated specifically,

The purpose of the law is to encourage governmental owners or lessees of property to make land available to the public for skateboarding, inline skating, paintball, and freestyle or mountain and off-road bicycling. It is recognized that governmental owners or lessees of property have failed to make property available for such activities because of the exposure to liability from lawsuits 
and the prohibitive cost of insurance, if insurance can be obtained for such activities. It is also recognized that risks and dangers are inherent in these activities, which risks and dangers should be assumed by those participating in such activities. (section 1)

The Florida legislation has some special clauses in it. For negligence to be waived, no one under the age of 17 can use the park without having signed permission from a parent or guardian (section.3). While the statute protects governmental entities, it does not protect private agencies even if they are providing the service for the government (section 6).

North Carolina passed similar legislation in 2003 but indicated that if a governmental entity provides a specific facility for hazardous recreation activities and there is a warning provided, they cannot be held liable for injury. This immunity is only available to the government and only at special, designated facilities (N.C. Gen. Stat. § 99E-25 (2013)).

Eighteen states (AK, CA, HI, FL, IA, IL, IN, LA, MT, NE,NC, SD, TN,TX, UT, VA, WI, WY) have added this kind of protection with a special statute (see Table 1). Some just state the provider is not liable for inherent risks of the activity (AK, MT, UT, WI, WY). Some stipulate that the agency is not liable for assumption of risk if a warning is posted (NE, TX) In Nebraska for example the statement on the sign must say "Under Nebraska law, a political subdivision is not liable for an injury to or the death of a participant in recreational activities resulting from the inherent risks of the recreational activities pursuant to section 13-910" (RRS Neb. 13-27). Indiana adds that rules must be posted. Some states include exceptions to the immunity for design, construction or maintenance(CA, HI, IA) The rest of the states that have these statutes give full immunity for these activities (IL, SD, TN VA).

\section{Liability Caps}

There are still states where there is no immunity or exceptions for parks and recreation agencies to offer their services. Some of these states that waived immunity compromised so that cities are somewhat protected. Fifteen states allow lawsuits but cap the amount that can be collected in a single suit or suits with multiple injuries when the injury was caused by negligence of a government agency. The reasoning behind these statutes is that the government knows how large their insurance policy needs to be and is assured that if there is a significant injury, the injured will receive no more than the cap. This compromise allows the injured individual to collect while providing some protection to the state. The caps in these states range from Rhode Island at a low of \$100,000 (Gen. Laws 1956, § 9-31-1, (2013)) to a high in Indian at \$5 million for death (Burns IN Code Ann\$ 34-13-3-4 (2013).

Of course, if there is no cap, communities often turn to insurance; that is, if the government is found liable, an insurance company will pay the damages. There are still seven states that seem to have none of these protections. These states have no more protection than the average citizen. While research was not done to determine the effect of lack of protection, it may mean that certain activities are simply not provided by the government agencies.

The following map indicates the strongest method of immunity protection used by each state. While some have more than one type of protection, the one that seems to provide the best protection for recreation and sport is identified for each state. 
The map does not show how strong the protection is. For example, 16 states have hazardous recreation statutes with many of them taking the form of assumption of risk statutes simply stating that the government will not be liable for inherent risk of hazardous recreation activities (AK, FL, UT, WI, WY). That actually is no more protection than if there was no statute. Other special statutes are just for particular activities like skateboarding (HI), yet others include all recreation activities (SD).

Using the dates that each of these laws were passed Figure 2 was created so that one can see how immunity slowly gave way to recreational user statutes and when that was not effective, to new laws so high risk activities could be provided to meet the public demand while protecting the tax dollars.

Sovereign immunity began to be repealed even before the Federal Tort Claims Act was enacted. Three states (LA, MT, and NY) had waived immunity before 1946. The graphic timeline starts in 1946 at which time 47 states still had immunity. The 1980s was the decade when the fewest states (25) had governmental immunity protection. Demand from the public to have an outlet for their recreation interests even though the activity may be risky, required legislatures to provide solutions. The graph indicates how many states had protection and then how it was divided by the type of protection. What Figure 2 does not show is that while one state may give up one type of immunity another state may have added it. By 2013 all but seven states maintain some sort of protection.

\section{Conclusion}

The hypothesis for this study was that as immunity is waived for negligence in provision of recreation services, states will eventually pass another statute so that they can continue to offer services that are demanded by the public. The desire of

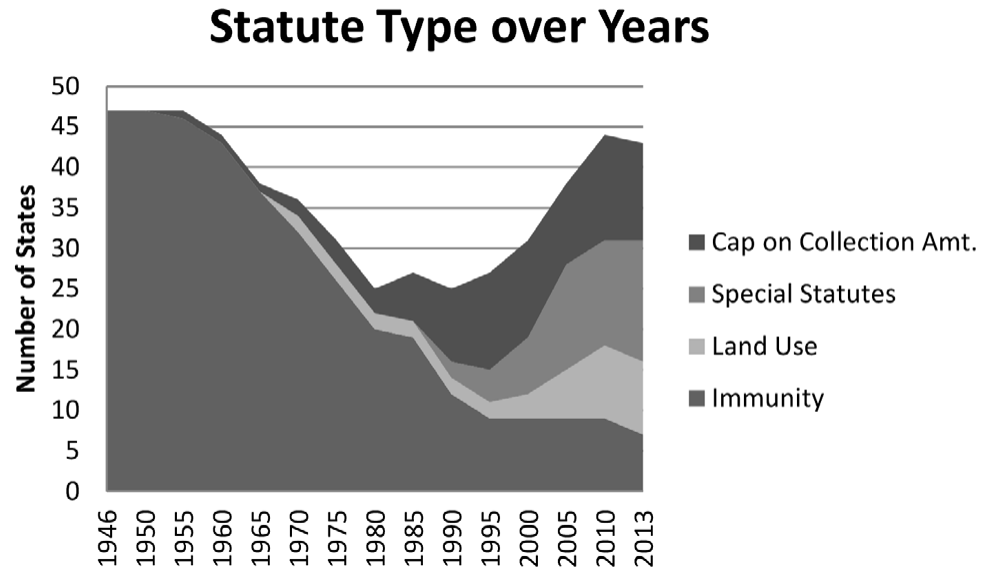

Figure 2 - Changes in methods of protection over years. 
every recreation and parks department is to provide the services that citizens want. However, they have a fiduciary duty to protect the tax dollars and to make the best use of the money. The balance of being fair to the citizen who is injured due to negligence by the city or its agents and providing those services is the issue at hand. Each state has grappled with the issue and most have determined a solution different from either the original, broad sovereign immunity statute or striking immunity all together. This clearly indicates that if immunity is lost, the states will legislate a method for service providers to meet the demands of their citizens.

Taking a broader view, it also shows that legislatures can be creative in their solutions. As problems occur and solutions need to be found, there are many answers to the same question, it does not have to be a "one size fits all approach." They will find balance through compromise.

\section{References}

Note. State laws that are referenced can be found in Table 1.

Arizona Revised Statutes. § 33-1551 (2013).

Bronsen v. Dawes County, 722 NW 2d 17 (NE 2006)

Bronsen v. Dawes County, 704 N.W.2d 273 (Neb App 2005)

Carroll, M.S., Connaughton, D., \& Spengler, J.O. (2007). Recreational user statues and landowner immunity: A comparison study of state legislation. Journal of Legal Aspects of Sport, 17(2), 163-191.

Chisolm v. Georgia (1793) 2 U.S. 419

Dickey v. City of Flagstaff 66 P3rd 44 (AZ 2003)

Hall, M.A., \& Wright, R.F. (2006). Systematic content analysis of judicial opinions. California Law Review, 96, 1-24. Retrieved from http://ssrn.com/abstract=913336.

Kaiser, R.A., \& Wright, B.A. (1994). Liability and immunity: A national assessment of landowner risk for recreational injuries. Washington, D.C.: USDA Soil Conservation Service., retrieved from http://www.tamu.edu/faculty/rakwater/research/Liability_and_Immunity.pdf.

Latoof, B \& Gofen, C. (1988, Oct. 6). Skateboard enthusiasts seek place to safely ride. St. Petersburg Times. P. 3.

Nelson, S.L. (2009). The King's wrongs and the federal district courts: Understanding the discretionary function exception to the Federal Tort Claims Act. South Texas Law Review, 51, 259-304.

Perkins v. State of Indiana (1969) 251 N.E.2d 30

Pfander, J.E. (1998). History and state suability: An "explanatory" account of the eleventh amendment. Cornell Law Review, 83, 1269-1382.

Schogol, M. (2002, March 27) As skateboarding takes off, parks are following. Philadelphia Inquirer, p.1.

Sloan, J. (2007, January 3) Chill falls on winter fun. Omaha World Herald. p. 1A

Sutton, C. (1988, May 8) Plans for skateboard have face uphill fight. St Petersburg Times p.1.

U.S. Code $\$ 2674$ Liability of the United States

U.S. Const. Amend. XI

Zabel, M.L. (2003). Advisory juries and their use and misuse in Federal Tort Claims Act cases. Brigham Young University Law Review, 185, 185225. 